DOI https://doi.org/10.18551/rjoas.2018-11.14

\title{
PARTICIPATION CUSTOMER ON E-COMMERCE: RELATIONSHIP PERCEIVED RISK, SECURITY, TRUST, AND CONSUMER PROTECTION
}

\author{
Ardhiani Mutiara Rachma*, Soewarno Noorlailie \\ Faculty of Economics and Business, University of Airlangga, Indonesia \\ *E-mail: mutiara.rachmaardhiani@gmail.com
}

\begin{abstract}
The purpose of this study is to determine the effect of risk perception, security, and trust on e-commerce customer participation in Indonesia. This research also wants to know whether with the role of state law in Indonesia, through Consumer Protection Act (CPA), able to moderate risk perception and trust to e-commerce customer participation. This research was conducted in Indonesia with 184 respondents e-commerce customers. Testing was done using Moderated Regression Analysis and SPSS 23 program. The result of this research shows that security and influence variables influence customer participation. While the perception of risk does not affect the customer's participation. Another result of this research is the interaction of moderation variable of consumer protection on risk perception and trust does not give influence to customer participation.
\end{abstract}

\section{KEY WORDS}

Consumer protection, business, marketing, transaction system, Indonesia.

The Internet is a tool that can be used for various activities such as business, communications, and other electronically. With the Internet, anyone can connect, including businessmen and even the company, resulting in a change in the system, either directly or indirectly, such as trading systems, marketing systems, and transaction systems. Various kinds of new things with the development of the Internet is increasingly widespread, one of which is an online marketplace. The use of the internet and the web for the purpose of business transactions called Electronic Commerce (e-commerce) (Laudon \& Laudon, 2014).

The process of transactions through e-commerce involves two parties to exchange goods, services, or information with the Internet as the main media. Transactions on ecommerce in practice can occur between business organizations with fellow business organizations (B2B) and between business organizations and consumers (B2C) (Laudon \& Laudon, 2014; O'Brien \& Marakas, 2007). There are several ways to classify e-commerce trading transactions. One way is to see who the participants are in the transaction. There are three major categories of e-commerce, business-to-consumer (B2C), business-to-business (B2B), and consumer-to-consumer (C2C).

The number of internet users in Indonesia in 2016 is 132.7 million or about $51.5 \%$ of the total population of Indonesia (256.2 million people) (APJII, 2016). Most Internet users are on the island of Java with a total of $86,339,350$ users or about $65 \%$ of total internet users. When compared to 2014 , which was only 88.1 million users, there was an increase of 44.6 million within 2 years (APJII, 2017). These conditions can be a driving force for growing ecommerce in Indonesia. The growing number of internet users, it will affect the behavior of people in making purchases, from previously conventional purchasing switch to purchase via e-commerce. E-Commerce much preferred because of the convenience and ease of making transactions. Transactions in e-commerce can be through electronic media such as telephone, fax, ATM, mobile phone, SMS, ATM phone banking, internet banking that is specifically connected to the Internet.

Doing transactions online is certainly riskier when compared to offline transactions. Research conducted by Suresh \& Shashikala (2011) found that a higher perception of consumer risk occurred in online purchase transactions than buying through stores. If the level of risk is high, then it will make the consumer uncomfortable in using e-commerce so 
that e-commerce will be lack of enthusiasts. Perception of risk then affects consumers in conducting transactions through e-commerce.

Business transactions conducted through the internet does not mean to avoid the evil of others. The process in e-commerce should also be supported by secure access between parties in e-commerce transactions by authenticating users, authorizing access, and enforcing security features (O'Brien \& Marakas, 2007). Potential crimes of fraud, password theft, credit card hijacking, illegal transfer of funds from certain accounts, and the like are great if the e-commerce security system is weak. Therefore, security in e-commerce is a matter of concern for e-commerce site providers.

Shopping via e-commerce requires accurate information about the items being sold. The more information you get, the more interested customers will buy. With the increasing number of buyers, then the participation of customers will also increase. There are many factors that cause a person to shop through e-commerce. Starting from the low cost, the quality of goods type, trust, the facility of ease of transaction, up to several other factors. A very important factor for influencing the interest of online purchasing is the trust factor (Pavlou \& Gefen, 2002). The trust factor is a key factor in every online transaction. High efforts must be made by the seller to increase consumer confidence because trust has a big influence on the intention of consumers to conduct transactions online or not do it. Therefore if there is no trust between seller and buyer then there will be no transaction in e-commerce.

Research result by Corbitt, Thanasankit, \& Yi (2003) resulting in increased consumer participation in e-commerce is directly related to the web experience, market orientation, and trust. The results of the study are also supported by research from Mukherjee \& Nath (2003) who found that consumer commitment in using e-commerce is directly related to shared values (ethics, security, and privacy) and trust. Risks in e-commerce can be reduced by establishing good communication between the two parties who transact, including through the presentation of relevant information.

E-commerce transactions create a more practical business transaction system, paperless and do not need to meet directly with the transacting party, so e-commerce has the potential to become a new driver for the economy. In addition to these advantages, the negative aspect of this development is related to security issues in transactions using ecommerce media. There is a bad possibility that will appear as a form of fraud that tends to harm consumers and cause various legal problems in conducting transactions.

On buying and selling through the internet, often find a fraudulent. Such frauds may occur with respect to the existence of business actors, purchased goods, prices of goods, and payments by consumers. Such a fraud concerns the seller, such as the place of business (virtual store) is a fictitious shop. Regarding goods sent by the seller, for example, the goods are not delivered to the consumer or there is a prolonged delay in delivery, there is damage to the goods delivered or the goods delivered defects, and others.

Regarding the order and payment by consumers who are denied the truth by businesses. For example, the seller only recognizes that the amount of goods ordered is less than that stated in the purchase are sent electronically or price per unit of goods ordered by the consumer is said to be higher than the price listed in the purchase. Can also occur entrepreneurs claimed to have received payment from consumers, when in fact the consumer is sent a payment for the whole price of the goods. With bad possibilities that can arise through e-commerce as it is the rights of consumers need to be protected.

Indonesia has a Consumer Protection Act (CPA) which protect consumers right. In CPA No. 8 Article 1 Paragraph 2 of 1999 about Consumer Protection, defines consumers as users of goods and/or services, either for themselves or others and not for sale. of the definition, then the consumer is the end user of the transaction. According to the Act, there are basic rights of consumers to be protected, one of which is the rule of law. Legal security guarantees for consumer e-commerce is necessary to protect consumers from the negative effects they might experience, and grow their confidence that through e-commerce transactions is increasing.

The purpose of this study was to determine the effect of the perception of risk, security, and confidence in e-commerce customer participation in Indonesia. This study also wanted 
to know whether the role of state law in Indonesia, through the Consumer Protection Act (CPA), able to moderate perceived risk and confidence in e-commerce customer participation. This research was conducted in Indonesia with 184 respondents e-commerce customers.

\section{LITERATURE REVIEW}

Customer Participation. Participation is a person's involvement in an activity. Customer participation has been widely studied in the business-to-consumer (B2C) context, and the participation of business customers who have been largely scrutinized (Mustak, Jaakkola, \& Halinen, 2013). In the context of e-commerce, the measurement of participation by looking at the number of consumers in making transactions (Kim, Lee, Lee, Ferrin, \& Rao, 2003). Customer participation in e-commerce requires customer decisions in environments that have opposite factors (eg, perceptions of risk and trust) (Gurung \& Raja, 2016). Customer participation can also be defined as the extent to which customers provide information, follow suggestions, and engage in joint decision making (Gallan, Jarvis, Brown, \& Bitner, 2013). Customer participation determines the extent to which customers place their efforts and resources into the production process so as to take part in consuming and producing value (Chih-cheng, Chen, \& Chen, 2017).

Customers will increase their participation if they believe in partners, media, or anything else involved in an activity. Such trust can not be built simply. Each customer has a perception of each risk. So it is necessary for the seller to provide very clear information so that customers feel safe and lower their negative perceptions. The security of their personal information also needs to be maintained. Customers will be more comfortable in the transaction if the seller guarantees their personal data. Therefore, it is important for the seller to pay attention to the risks, security, and consumer confidence that they wish to participate in e-commerce activities (Gurung \& Raja, 2016).

Perceived Risk. The risk is a state of uncertainty that consumers consider to decide whether to make transactions online or not. One would really consider distance, impersonal mood during online transactions, and support infrastructure that contains many elements of risk. The risk is defined as a subjective estimate of the consumer in which they will suffer harm for the intended purpose (Pavlou \& Gefen, 2002). When consumers have little information about a product or a seller, the risks will be higher. Perceived risk can be defined as a consumer's perception of the uncertainty and avoidance of the consequences that he may receive from the transaction (Chang \& Tseng, 2011). As the internet grows, consumers' attention to risks is high. This perception prevents consumers from engaging in an online transaction. Perceived risks in this study are the consumers' negative perceptions of a number of activities based on the presence of negative outcomes and possible adverse events that may occur when conducting online transactions.

Security. Consumers may have concerns about the flow of information between online consumers and websites, as well as how their personal data is managed by the website (Gurung \& Raja, 2016). Therefore, security is a matter of concern for e-commerce site providers. Security in the context of e-commerce can be defined as e-commerce capability in controlling and maintaining the security of transaction data and personal data of the customer. Security guarantees play an important role in the establishment of a sense of security by reducing consumer concerns about the misuse of personal data and transactions. If the consumer assumes that the website of the online seller offers security, such as security policy, secure shopping warranty, and other protection mechanisms, then the consumer will conclude that the seller provides security guarantees during online transactions (Chellappa \& Pavlou, 2006).When the security guarantee is acceptable and in accordance with consumer expectations, then the consumer will probably be willing to disclose personal information and will buy with a sense of security. The more customers feel secure against the security of ecommerce sites, then the customer will judge the site reliably (Kim, Ferrin, \& Rao, 2008)

Trust. Trust plays an important role in e-commerce (Gefen, 2002). A business transaction will not happen if the two or more parties do not trust each other. This belief is not 
simply to be acknowledged by other parties/business partners, but must be built from the beginning and can be proven. Trust is a major challenge for the rapid development of online transactions, but a factor that affects e-commerce success because it is a factor that is the main consideration of consumers to establish whether or not to transact via e-commerce (Limbu, Wolf, \& Lunsford, 2012). Some literature has defined trust in various approaches (Mukherjee \& Nath, 2003). Kim, Ferrin, \& Rao (2008) define trust as the subjective belief of consumers regarding online sellers who will fulfill their transactional obligations. Pavlou \& Gefen (2002) define trust is the assessment of one's relationship with another person who will perform certain transactions according to the believer's expectations in an uncertain environment. In other words, trust is a form of confidence of a particular party against another party in a transaction, which he considers will meet all obligations as expected.

Consumer Protection. The emergence of the concept of consumer rights protection is the Caveat Venditor theory (beware the seller) (Balleisen, 2017). This theory emphasizes that the seller must be good faith and responsible in selling the product. The seller must also provide protection and provide clear and honest product information. Consumers who do not have enough information about the product being offered can be wrong in determining the choice. So often we know the word "be careful before buying" because there is the possibility of dishonest and unfair sellers in transactions. This is important because when consumers find items that are purchased defective or not as promised, they will find it difficult to ask for compensation. The seller will ask the consumer to prove that the damage was not due to a deliberate mistake made by the consumer so that the consumer can get compensation. To protect consumer rights in Indonesia, the Indonesian government passed Consumer Protection Act (CPA) No. 8 of 1999 on Consumer Protection which became effective on April 20,2000 . CPA pretty much regulates the behavior of business actors. This is understandable given the loss consumers suffer from the goods or services they buy, which is the result of dishonest behavior of the seller.

The definition of consumer protection contained in Article 1 (1) on CPA is any effort that ensures the existence of legal certainty to provide protection to consumers. The definition of consumer protection definition contained in Article 1 (1) is sufficient. With the enforcement of these regulations, it is expected to be a protector for consumers of any harmful actions they may receive from the seller. Legal certainty to provide protection to the consumer, among others, is to improve the consumer's dignity and also to open access to information about goods and/or services for him, and to foster an honest and responsible business actor attitude.

Hypothesis. As described in the previous section, participation is measured by the number of consumers making transactions. There are various factors that can influence consumer desire to transact, one of which is perceived risk. Perceived risk is a state of uncertainty that a person considers to decide to make an online transaction. The risk is defined as the subjective estimate of the individual in which he will suffer a loss in receiving the desired result (Pavlou, 2003). In the context of online transactions, individuals tend to perceive risks when uncertainty arises over possible outcomes of transactions made. There are two forms of uncertainty in online transactions, namely the uncertainty of behavior and environmental uncertainty. Research conducted Alalwan, Dwivedi, Rana, \& Williams (2016) shows that intentions and behaviors in e-commerce transactions are strongly influenced by usability perceptions, perceptions of ease of use, and perceptions of risk. Along with the research, the research from Kim, Ferrin, \& Rao (2008) perceived risks have a strong influence on purchasing decisions over the internet. Based on this matter then researcher concludes that the smaller the perceived risk, the more secure the customers will be, increasing their participation in e-commerce transactions, and proposed the following hypothesis:

H1. Perceived risk affects customer participation. Security is the ability of e-commerce in controlling and maintaining security of data transactions (Park \& Kim, 2006). Security guarantees play an important role in the formation of consumer confidence by reducing their concern about the misuse of personal data and corrupt transaction data. When the level of security assurance is acceptable and in line with consumer expectations, a consumer may 
be willing to provide his personal information and will purchase with a feeling of security. Research Raman \& Annamalai (2011) through a study conducted on online consumers in Malaysia, found that security factors have a positive and significant relationship in influencing purchasing decisions online. Consumers will not make purchases without security guarantees. Because without adequate security guarantees it will certainly cause concern to consumers, which ultimately prevents them from making a purchase. And conversely when the webstore able to improve security and provide assurance to consumers then consumer confidence in shopping will increase. From the explanation, the researcher proposed the following hypothesis:

H2. Security affects customer participation. In e-commerce, buyers and sellers do not meet directly during the transaction process so trust is the key to the transaction. Corbitt, Thanasankit, \& Yi (2003) examines customer participation in e-commerce in terms of the direct influence of perceived trust, experience of internet usage (user's web experience), and understanding of market orientation (perceived market orientation). The result of the study is that people with higher site quality perceptions have a higher level of perception on market orientation and trust in e-commerce. Furthermore, people with high levels of trust are more likely to participate in e-commerce. Positive "Word of mouth", money back guarantee and partnership with renowned business partners, are strategies that can effectively risk exposure. In addition, Gurung \& Raja (2016) examines how the effects of privacy, security, trust, perceived risks, attitudes, and subjective norms on the intentions of consumer transactions on online companies. From the results of these studies, confidence becomes the biggest effect in determining consumer attitudes. The results stress that trust plays an important role in shaping consumer attitudes. The research from Ponte, Carvajal-Trujillo, \& Escobar-Rodríguez (2015) also gave similar results, where the intention of buying online is influenced by the perception of value and trust. Therefore, when the seller is able to maintain consumer confidence with both, the consumer will be happy to continue to transact and increase the intensity of the transaction. Maybe in a certain circumstance, consumers will recommend to other consumers to make purchases via e-commerce sites. From the exposure, it can be taken as follows hypothesis:

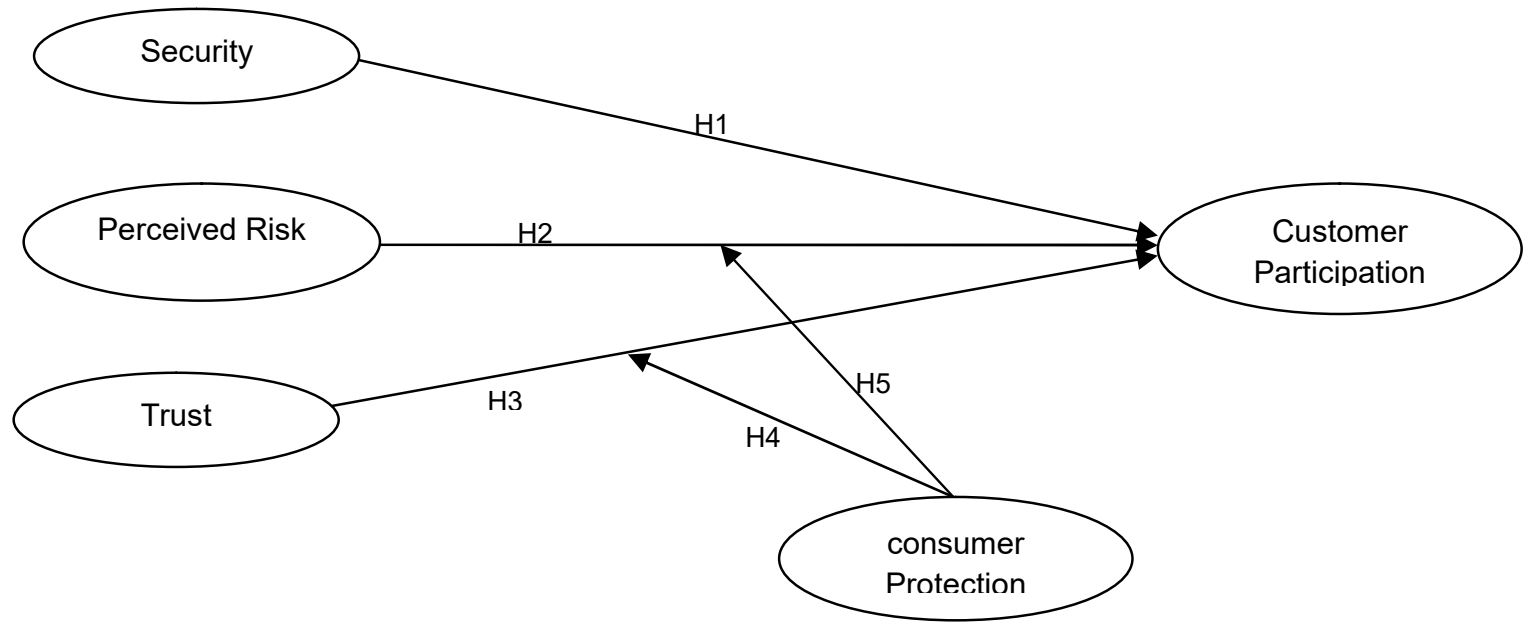

Figure 1 - Conceptual Framework

H3. Trust affects customer participation. The use of global internet computer networks for commercial activity is increasing rapidly and the growing uncertainty is also greater (Jawahitha, 2005). Transactions through e-commerce certainly also have risks. Customers will assess what risks they may receive when transacting through the medium. The higher the risks, the higher the reluctance of consumers to transact on e-commerce. Customers are also increasingly unwilling to trade through e-commerce if their confidence level to sellers is low. Trust in e-commerce transactions is the key to making transactions work, and many studies have proven it (Corbitt, et.al., 2003; Gurung \& Raja, 2016; Ponte, et. al., 2015). Belief does not appear out of nowhere, but must be built from scratch and can be verified. 
However, a variety of cases involving e-commerce make reduced consumer confidence. A country must have special rules aimed at the interests of consumers, such as Indonesia with CPA No. 8 of 1999 about Consumer Protection. With the absence of legal protection, are expected to positively affect customer confidence and perceptions of risk. Of the exposure, the researchers proposed a hypothesis:

H4. Moderation consumer protection affect consumer perceived risks toward customer participation.

H5. Moderation consumer protection affect consumer confidence in customer participation.

\section{METHODS OF RESEARCH}

Collecting data using closed-ended questionnaires distributed offline and online via Google Form. There are as many as 184 respondents in this study. Penggukuran scale adopted some prior research and make a few changes to suit the context of e-commerce. Perceived Risk (PR) using 4 items adopted from Gurung \& Raja (2016), Security using seven items adopted from Ponte et al. (2015) and Singh, Srivastava and Sinha (2016), Trust consists of eight items were adopted from Gurung \& Raja (2016) and Mou, Shin, \& Cohen (2016), Consumer protection consists of nine items that are based on the Corodeanu (2015) and adapted to CPA No. 8 of 1999. Participation of customers using the 3 items adopted from Tung, Tan, Chia, Koh, \& Yeo (2001), Corbitt, Thanasankit, \& Yi (2003), and Ratnasingham \& Kumar (2004).

Measurements using Likert scale with 1-strongly disagree to 5-strongly agree. Specifically on the perceived risk variable used Likert scale measurements in reverse, 5strongly disagree to 1-strongly agree. This is because the proposed statement is negative. Furthermore, the data were analyzed with Moderated Regresion Analysis through SPSS 23.

Regression formulas:

$$
\begin{gathered}
\text { CPrt }=\alpha+b 1 \text { Security }+b 2 P R+b 3 \text { Trust }+e 1 \\
\text { CPrt }=\alpha+b 1 \text { Security }+b 2 P R+b 3 \text { Trust }+b 4 \text { Risk }{ }^{*} \mathrm{CPo}+b 5 \text { Trust }{ }^{*} \mathrm{CPo}+\mathrm{e} 2
\end{gathered}
$$

\section{RESULTS OF STUDY}

The number of respondents in this study was 184 respondents. By gender, the respondents consisted of 71 men (38.6\%) and 113 females $(61.4 \%)$. If grouped by age, most respondents were $21-25$ years old (114 respondents or $62 \%)$, followed by $31-35$ years old as 24 respondents (13\%), 26-30 years as many as 23 respondents $(12.5 \%)$, below 20 years as many as 14 respondents $(7.6 \%)$, and over 35 years as many as 9 respondents $(4.9 \%)$. In qualification, most respondents are Bachelor qualification, that is 133 respondents $(72,3 \%)$. Furthermore, the respondents with High School and Master qualifications are the same, each of which is 23 respondents (12.5\%). Respondents with Diploma qualification as many as 5 respondents $(2.7 \%)$. And in this study there were no respondents with a Ph.D. qualification.

Table 2 shows the test results between variables partially prior to the interaction of the moderating variables. From the table obtained the result that the PR has no effect on Customer Partcipation with t-value 1.564 and sig. $0.120(>0.05)$, then $\mathrm{H} 1$ is rejected. While for Security and Trust is significant at $0.000(<0,05)$ and has t-value respectively of 6,503 and 5,200 . By looking at these results, then $\mathrm{H} 2$ and $\mathrm{H} 3$ are accepted.

PR has no effect because customers may not care about risk so in this study the risk is not influenced by their participation in using e-commerce. Security and Trust significantly influence Customer Participation. This shows the more secure an e-commerce, the higher their participation. Likewise with Trusts, customers believe in sellers and e-commerce systems so the more customers believe in e-commerce, the higher is their participation.

Table 3 above shows a significant influence between independent variables with dependent variable. ANOVA test showed $F=37,222$ and significant at $0.000(<0,05)$. This 
shows that the variables PR, Security, and Trust simultaneously affect Customer Paticipation.

Table 1 - Demographic profile of respondents

\begin{tabular}{ccc}
\hline Demographic Profile & Number $(\mathrm{N})$ & Percent \\
\hline Gender & 71 & 38,6 \\
Male & 113 & 61,4 \\
Female & & 7,6 \\
Age & 14 & 62,0 \\
Under 20 years & 114 & 12,5 \\
$21-25$ years & 23 & 13,0 \\
$26-30$ years & 24 & 4,9 \\
31-35 years & 9 & 12,5 \\
Above 35 years & & 2,7 \\
Qualification & 23 & 72,3 \\
High School & 5 & 12,5 \\
Diploma & 133 & 0
\end{tabular}

Table 2 - Testing Perceived Risk, Security, and Trust variables on Customer Participation

\begin{tabular}{|c|c|c|c|c|c|c|}
\hline & \multirow{2}{*}{ Model } & \multicolumn{2}{|c|}{ Unstandardized Coefficients } & \multirow{2}{*}{$\frac{\text { Standardized Coefficients }}{\text { Beta }}$} & \multirow{2}{*}{$\mathrm{t}$} & \multirow{2}{*}{ Sig. } \\
\hline & & $B$ & Std. Error & & & \\
\hline \multirow{4}{*}{1} & (Constant) & ,753 & ,289 & & 2,608 & 010 \\
\hline & Risk &, 067 &, 043 & ,092 & 1,564 & 120 \\
\hline & Security & ,353 & 054 & ,406 & 6,503 & ,000 \\
\hline & Trust & ,350 & ,067 & ,327 & 5,200 & ,000 \\
\hline
\end{tabular}

a. Dependent Variable: CPrt

Table 3 - One-way analysis of variance (ANOVA) relationships between variables before being interacted by moderating variables

\begin{tabular}{lrrrrr} 
ANOVA $^{\mathrm{a}}$ Model & \multicolumn{1}{c}{ Sum of Squares } & \multicolumn{1}{c}{ df } & Mean Square & F & Sig. \\
\hline 1 Regression & 22,712 & 3 & 7,571 & 37,222 &, $000 \mathrm{~b}$ \\
Residual & 36,610 & 180 &, 203 & & \\
Total & 59,322 & 183 & & & \\
\hline
\end{tabular}

a. Dependent Variable: CPrt

b. Predictors: (Constant), Trust, Risk, Security

Table 4 - Testing with the interaction of moderation variables (Customer Protection) on PR and Trust

\begin{tabular}{ccccccc}
\hline \multirow{2}{*}{ Model } & \multicolumn{2}{c}{ Unstandardized Coefficients } & Standardized Coefficients & t & Sig. \\
& B & Std. Error &, 093 & & 3,837 &, 000 \\
& (Constant) &, 357 &, 035 &, 091 & 1,560 &, 121 \\
Ln_Risk &, 054 &, 046 &, 379 & 6,022 &, 000 \\
1 & Ln_Security &, 275 &, 105 &, 216 & 2,178 &, 031 \\
Ln_Trust &, 228 &, 047 &, 166 & 1,669 &, 097 \\
\hline
\end{tabular}

a. Dependent Variable: Ln_CPrt

Tabel 5 - Excluded Variables

Excluded Variables $^{a}$

\begin{tabular}{|c|c|c|c|c|c|c|c|}
\hline \multirow[b]{2}{*}{ Model } & \multirow[b]{2}{*}{ Beta In } & \multirow[b]{2}{*}{$\mathrm{t}$} & \multirow[b]{2}{*}{ Sig. } & \multirow[b]{2}{*}{ Partial Correlation } & \multicolumn{3}{|c|}{ Collinearity Statistics } \\
\hline & & & & & Tolerance & $\mathrm{VIF}$ & Minimum Tolerance \\
\hline $1 \mathrm{Ln}$ Mod RiskCPo & $-24,065 b$ & .820 & 413 &,- 061 & $3,931 \mathrm{E}-6$ & 254370,499 & $3,931 \mathrm{E}-6$ \\
\hline
\end{tabular}

a. Dependent Variable: Ln CPrt

b. Predictors in the Model: (Constant), Ln_Mod_TrustCPo, Ln_Risk, Ln_Security, Ln_Trust 
During testing by interpreting Customer Protectin (CPo) moderation variables in PR and Trust, there are multicolonierity symptoms (see Appendix II). After re-test, the cause of the multicolonierity is CPo interaction with PR (t-value $=-0.820$ and significance of 0.413 ) so that $C P O^{*} P R$ interaction is excluded from the calculation (Table V). Results after retesting (Table IV) show that there is no interaction of the moderating variables. From the test results, then $\mathrm{H} 4$ and $\mathrm{H} 5$ are rejected.

The absence of interaction from CPo with Trust (CPo*Trust) is due to customers already believing in e-commerce sites. This can be seen from the Trust significance value of $0,000(<0.05)$ indicating the strong influence of this variable on customer participation. Therefore, the existence of legal protection for them is not necessary. Likewise with CPo interaction with PR (CPo*PR). In the first test, there is no influence of PR on customer participation, so in this case consumer protection becomes unnecessary.

Table 6 - One-way analysis of variance (ANOVA) relationships between variables after being interacted by moderating variables

\begin{tabular}{ccccccc}
\multicolumn{1}{c}{ ANOVA $^{\mathrm{a}}$} & \multicolumn{1}{l}{} & & & \\
\hline & Model & Sum of Squares & $\mathrm{df}$ & Mean Square & $\mathrm{F}$ & Sig. \\
\hline & Regression & 23,374 & 5 & 4,675 & 23,149 &, $000 \mathrm{~b}$ \\
& Residual & 35,947 & 178 &, 202 & & \\
\hline & Total & 59,322 & 183 & & & \\
\hline
\end{tabular}

a. Dependent Variable: CPrt

b. Predictors: (Constant), Mod_TrustCPo, Risk, Security, Trust, Mod_RiskCPo

Table 6 above shows a significant influence between independent variables with dependent variable. ANOVA test showed $F=23,149$ and significant at $0,000(<0,05)$. This shows that the variables $\mathrm{PR}$, Security, Trust, interaction $\mathrm{PR}^{*} \mathrm{CPo}$, and interaction Trust ${ }^{*} \mathrm{CPo}$ simultaneously affect Customer Paticipation.

\section{DISCUSSION OF RESULTS}

Customers have a willingness to buy from e-commerce as a medium to transact. Based on the results of this study, perceived risks have no effect on customer participation in Indonesia. The results of this study contradict Alalwan, Dwivedi, Rana, \& Williams (2016) and Kim, Ferrin, \& Rao (2008) where their research results prove that perceived risk affects intentions, behavior, and purchasing decisions via e-commerce. The results of this study indicate that customers do not consider the risks they will receive. This may be because the customer already has experience, whether it's personal experience or other people's experience, about transaction activity on e-commerce site (Chang \& Tseng, 2011). Previous experiences in online purchases help them to decide whether they are willing to make a purchase or not (Alharbi, Zyngier, \& Hodkinson, 2013). The study by Gurung \& Raja (2016) also proves that there is no significant influence on the perception of risk to online purchase intentions. In addition, Zhang, Tan, Xu, \& Tan (2012)studies show that not all perceived risk dimensions consist of perception of health risk, perception of quality risk, perception of privacy risk, perceptions of economic risk, perceptions of time risk, social perceived risk, perception delivery risk, and perceived risk after sales, affecting consumer e-commerce buying behavior. Perceptions of privacy risks, perceptions of economic risk, and perceptions of social risks are irrelevant to e-commerce customers. Similarly, Beneke, Greene, Lok, \& Mallett (2012) found that financial, physical, psychological, and social risks had no effect on purchase intentions.

Furthermore, the results of this study indicate that the security effect on customer participation. This result is in line with Raman \& Annamalai (2011) where the study proves that security has a positive effect on online purchasing decisions. One way for customers to be satisfied and loyal is to understand customer value. These values can be defined as anything related to security (Encio, 2014). E-commerce managers must ensure their systems are supported by adequate security and hacker-free levels so that their personal data can be 
stored securely, and keep their servers and software as up-to-date operating systems. Ecommerce providers have more responsibility to protect their customers' privacy information because customers provide information that may be highly personal, such as credit cards, addresses, and phone numbers, free of charge for their transactions. E-commerce sites not only have to have a strong security infrastructure but must also describe themselves to consumers to make them more comfortable and confident so as to keep them going on the e-commerce activity.

Trust plays a very important role in transactions through e-commerce. In this study, the test results show that trust has a strong influence on customer participation. The results of this study are in line with Al-Debei, Akroush, \& Ashouri (2015) which states that consumer attitudes toward online shopping are determined by trust and perceived benefits. They also emphasize on his research that trust and perception of benefits are key predictors of consumer attitudes. These findings support research conducted by Corbitt, Thanasankit, \& Yi (2003) where trust has a positive and significant influence on the participation of e-commerce customers. Customers with high levels of trust are more likely to participate in e-commerce. In addition, research conducted Gurung \& Raja (2016) also gives the result that trust becomes the biggest effect in determining consumer attitudes. The results of the study from Ponte, Carvajal-Trujillo, \& Escobar-Rodríguez (2015) also do not produce many different results, where the research results that the intention of buying online is influenced by trust.

In this study indicates that consumer protection variables can not moderate, both on the perception of risk and trust. The logical discussion that can be derived from these findings is that when customers do not take into account the risks of their transactions on ecommerce sites, the legal protections protecting their rights will also be useless. Research conducted by Corodeanu (2015) shows that Generation Y (between 1980 and 2000) has the potential to solve crisis situations such as trust, freedom, and more flexibility. They will know how to react well and professionally in situations where rights violations occur. If you look at the average age of respondents in this research data, it can be said that the majority of respondents are in the category of Generation Y. So research from Corodeanu (2015) relevant to this test results. Furthermore, in the variable of trust, consumer protection also can not moderate the influence of these variables on customer participation. When viewed from the test results, trust has $\rho$-value $=0,000$, which signifies the strong influence of this variable on customer participation. When the customer has a very trustworthy e-commerce site, then the consumer protection is also unnecessary.

\section{CONCLUSION}

This study aims to determine the effect of perceived risk, security, and trust on ecommerce customer participation in Indonesia. This study also examines the role of state law in Indonesia, through the Consumer Protection Act (CPA), in moderating the perception of risk and trust towards the participation of e-commerce customers. The result of this research is security and trust influence to e-commerce customer participation. While the perception of risk does not affect the participation of e-commerce customers. This means that e-commerce customers in Indonesia do not take into account the risks they will receive from their activities in e-commerce. In this study, consumer protection is not able to moderate, both on the perception of risk and trust.

For e-commerce users in Indonesia, based on the results of research variables that affect the participation of customers is security and trust. While the perception of risk, the interaction of the moderation variable on the perception of risk and trust have no effect. Therefore, it is important for e-commerce site providers and other online businesses to always try to maximize what customers expect, to provide honest information to customers and nothing to hide, to maintain a reputation as a provider of e-commerce sites, to provide convenience (both in terms of data security and service) to customers in transactions so that customers can be satisfied, and responsible for transactions made with customers.

For e-commerce customers, although in this study the perception of risk does not affect the participation of customers, it is better if in transacting through e-commerce still take into 
account the risks that may arise. It is not enough to just learn from previous customer experiences because what they experience will not necessarily be the same. And for the regulator, despite the existence of legal protection efforts, but in this study, consumer protection law does not play a role in reducing negative perceptions and increase ecommerce customer confidence. Consumer protection laws should be more socialized to ecommerce users so they realize that their rights are legally protected.

Appendix - Questionnaire

\begin{tabular}{|c|c|c|}
\hline Variable & Description & Source \\
\hline \multirow{4}{*}{$\begin{array}{l}\text { Perceived } \\
\text { Risk }\end{array}$} & $\begin{array}{l}\text { There will be risks when I provide personal data information to an e- } \\
\text { commerce site. }\end{array}$ & \multirow{4}{*}{ (Gurung \& Raja, 2016) } \\
\hline & $\begin{array}{l}\text { There will be a high potential loss when I provide information to e- } \\
\text { commerce sites. }\end{array}$ & \\
\hline & $\begin{array}{l}\text { By providing information on e-commerce sites, it is possible for me } \\
\text { to face many unexpected problems. }\end{array}$ & \\
\hline & $\begin{array}{l}\text { There will be too many uncertainties associated with giving my } \\
\text { personal information to e-commerce sites. }\end{array}$ & \\
\hline \multirow{7}{*}{ Security } & $\begin{array}{l}\text { I feel secure with electronic payment systems from e-commerce } \\
\text { sites. }\end{array}$ & \multirow{2}{*}{$\begin{array}{l}\text { (Ponte, Carvajal-Trujillo, \& } \\
\text { Escobar-Rodríguez, 2015) }\end{array}$} \\
\hline & I feel safe in doing transactions on e-commerce sites. & \\
\hline & My personal data and bank are guaranteed on ecommerce site & \multirow{5}{*}{$\begin{array}{l}\text { (Singh, Srivastava, \& Sinha, } \\
\text { 2016) }\end{array}$} \\
\hline & My ID and password are not visible to anyone & \\
\hline & E-commerce sites can be accessed from anywhere and safe to use & \\
\hline & $\begin{array}{l}\text { I believe my personal information is stored in a secure and } \\
\text { encrypted database }\end{array}$ & \\
\hline & $\begin{array}{l}\text { I'm sure my personal information is not exposed to unauthorized } \\
\text { third parties }\end{array}$ & \\
\hline \multirow{8}{*}{ Trust } & $\begin{array}{l}\text { E-commerce sites have the skills and expertise to make transactions } \\
\text { in the expected way }\end{array}$ & \multirow{8}{*}{$\begin{array}{l}\text { (Gurung \& Raja, 2016; Mou, } \\
\text { Shin, \& Cohen, 2016) }\end{array}$} \\
\hline & $\begin{array}{l}\text { E-commerce sites have access to the information needed to handle } \\
\text { transactions appropriately }\end{array}$ & \\
\hline & The e-commerce site is fair in conducting customer transactions. & \\
\hline & $\begin{array}{l}\text { The e-commerce site is fair in its customer service policy after } \\
\text { making a transaction. }\end{array}$ & \\
\hline & The e-commerce site is open and accepts customer needs. & \\
\hline & $\begin{array}{l}\text { E-commerce sites always pay attention to the interests of their } \\
\text { customers during most transactions. }\end{array}$ & \\
\hline & The e-commerce site strives to address most customer issues. & \\
\hline & Overall, e-commerce sites can be trusted. & \\
\hline \multirow{9}{*}{$\begin{array}{l}\text { Customer } \\
\text { Protection }\end{array}$} & $\begin{array}{l}\text { When I am going to transact through an e-commerce site, the seller } \\
\text { provides complete information on the product. }\end{array}$ & \multirow{9}{*}{$\begin{array}{l}\text { (Corodeanu, 2015) } \\
\text { adjusted to UUPK No. } 8 \text { of } \\
1999\end{array}$} \\
\hline & $\begin{array}{l}\text { When I am going to transact through an e-commerce site for food, } \\
\text { cosmetic and drug products, the seller provides information on the } \\
\text { composition of the product. }\end{array}$ & \\
\hline & $\begin{array}{l}\text { On an e-commerce site, I get information about the impacts arising } \\
\text { from the product from the seller }\end{array}$ & \\
\hline & $\begin{array}{l}\text { On an e-commerce site, I get the expiry date information on the } \\
\text { product from the seller }\end{array}$ & \\
\hline & $\begin{array}{l}\text { On an e-commerce site, I get information about the guides on the } \\
\text { use of the products it sells }\end{array}$ & \\
\hline & $\begin{array}{l}\text { The product I order online, when it comes to the buyer has been in } \\
\text { accordance with the order and agreement when ordering and has } \\
\text { been in accordance with product specifications and information. }\end{array}$ & \\
\hline & The products I purchased on e-commerce sites are warranted. & \\
\hline & $\begin{array}{l}\text { When I have a problem, the complaint is well responded by the } \\
\text { seller }\end{array}$ & \\
\hline & $\begin{array}{l}\text { There is compensation for the complaints of goods I bought through } \\
\text { e-commerce sites. }\end{array}$ & \\
\hline \multirow{3}{*}{$\begin{array}{l}\text { Customer } \\
\text { Participation }\end{array}$} & I will continue to trade through e-commerce media. & $\begin{array}{l}\text { (Corbitt, Thanasankit, \& Yi, } \\
\text { 2003) }\end{array}$ \\
\hline & $\begin{array}{l}\text { I will increase the frequency of transacting through e-commerce } \\
\text { media. }\end{array}$ & $\begin{array}{l}\text { (Corbitt, Thanasankit, \& Yi, } \\
\text { 2003; Tung, Tan, Chia, Koh, \& } \\
\text { Yeo, 2001) }\end{array}$ \\
\hline & I would recommend to others to transact via e-commerce media. & $\begin{array}{l}\text { (Ratnasingham \& Kumar, } \\
\text { 2004; Tung, Tan, Chia, Koh, \& } \\
\text { Yeo, 2001) }\end{array}$ \\
\hline
\end{tabular}




\section{REFERENCES}

1. Al-Debei, M. M., Akroush, M. N., \& Ashouri, M. I. (2015). Consumer attitudes towards online shopping: The effects of trust, perceived benefits, and perceived web quality. Internet Research, 25(5), 707-733.

2. Alalwan, A. A., Dwivedi, Y. K., Rana, N. P., \& Williams, M. D. (2016). Consumer adoption of mobile banking in Jordan: Examining the role of usefulness, ease of use, perceived risk and self-efficacy. Journal of Enterprise Information Management, 29(1), 118-139.

3. Alharbi, I. M., Zyngier, S., \& Hodkinson, C. (2013). Privacy by design and customers ' perceived privacy and security concerns in the success of. Journal of Enterprise Information Management, 26(6), 702-718.

4. Asosiasi Penyelanggara Jasa Internet Indonesia (APJII). 2016. Accessed through www.apjii.or.id

5. Balleisen, E. J. (2017). American Better Business Bureaus, the Truth-in-Advertising Movement, and the Complexities of Legitimizing Business Self-Regulation over the Long Term. Politics and Governance, 5(1), 42-53.

6. Beneke, J., Greene, A., Lok, I., \& Mallett, K. (2012). The influence of perceived risk on purchase intent - the case of premium grocery private label brands in South Africa. Journal of Product \& Brand Management, 21(1), 4-14.

7. Chang, E., \& Tseng, Y. (2011). Research note: E-store image, perceived value and perceived risk. Journal of Business Research, 1-7.

8. Chellappa, R. K., \& Pavlou, P. A. (2006). Perceived information security, financial liability and consumer trust in electronic commerce transactions. Logistics Information Management, 15(5/6), 358-368.

9. Chih-cheng, Chen, V., \& Chen, C. (2017). The Role of Customer Participation for Enhancing Repurchase Intention. Management Decision, 55(3).

10. Corbitt, B. J., Thanasankit, T., \& Yi, H. (2003). Trust and e-commerce: a study of consumer perceptions. Electronic Commerce Research and Applications, 2, 203-215.

11. Corodeanu, D. A. (2015). Consumer's protection from the generation $Y$ ' s perspective . A research based on scenarios. Procedia Economics and Finance, 20(15), 8-18.

12. Encio, H. A. (2014). Consumers 'Perceptions on Privacy and Security in Ecommerce. Journal of Information Engineering and Applications, 4(4), 14-20.

13. Gallan, A. S., Jarvis, C. B., Brown, S. W., \& Bitner, M. J. (2013). Customer positivity and participation in services: an empirical test in a health care context. Journal of the Academic Marketing Science, 41, 338-356.

14. Gefen, D. (2002). Reflections on the Dimensions of Trust and Trustworthiness among Online Consumers. ACM SIGMIS Database, 33(3), 38-53.

15. Gurung, A., \& Raja, M. K. (2016). Online privacy and security concerns of consumers. Information \& Computer Security, 24(4).

16. Jawahitha, S. (2005). Cyberjurisdiction and consumer protection in e-commerce. Computer Law and Security Report, 21(2), 153-161.

17. Kim, D. J., Ferrin, D. L., \& Rao, H. R. (2008). A trust-based consumer decision-making model in electronic commerce: The role of trust, perceived risk, and their antecedents. Decision Support Systems, 44(2), 544-564.

18. Kim, D., Lee, K.-Y., Lee, D., Ferrin, D., \& Rao, R. (2003). Trust, Risk and Benefit in Electronic Commerce: What Are the Relationships? In Americas Conference on Information Systems (pp. 168-174).

19. Laudon, K. C., \& Laudon, J. P. (2014). Management Information Systems (Thirteenth). Pearson.

20. Limbu, Y. B., Wolf, M., \& Lunsford, D. (2012). Perceived ethics of online retailers and consumer behavioral intentions. Journal of Research in Interactive Marketing, 6(2), 133154.

21. Lui, H. K., \& Jamieson, R. (2003). Integrating Trust and Risk Perceptions in Business-toConsumer Electronic Commerce with the Technology Acceptance Model. In European Conference on Information Systems 2003. Naples. 
22. Mou, J., Shin, D., \& Cohen, J. (2016). Understanding trust and perceived usefulness in the consumer acceptance of an e-service: a longitudinal investigation. Behaviour \& Information Technology, 1-15.

23. Mukherjee, A., \& Nath, P. (2003). A Model of Trust in Online Relationship Banking. International Journal of Bank Marketing, 21(1), 5-15.

24. Mustak, M., Jaakkola, E., \& Halinen, A. (2013). Customer participation and value creation: a systematic review and research implications. Managing Service Quality, 23(4), 341-359.

25. O'Brien, J. A., \& Marakas, G. M. (2007). Management Information System (Tenth). New York: McGraw-Hill/Irwin.

26. Park, C.-H., \& Kim, Y.-G. (2006). The Effect of Information Satisfaction and Relational Benefit on Consumers' Online Shopping Site Commitments. Journal of Electronic Commerce in Organizations, 4(1), 70-90.

27. Pavlou, P. A. (2003). International Journal of Consumer Acceptance of Electronic Commerce: Integrating Trust and Risk with the Technology Acceptance Model. International Journal of Electronic Commerce, 7(3), 101-134.

28. Pavlou, P. A., \& Gefen, D. (2002). Building effective online marketplaces with institutionbasedtrust. In International Conference on Information Systems (Vol. 15(1), pp. 667675).

29. Ponte, E. B., Carvajal-Trujillo, E., \& Escobar-Rodríguez, T. (2015). Influence of trust and perceived value on the intention to purchase travel online: Integrating the effects of assurance on trust antecedents. Tourism Management, 47, 286-302.

30. Raman, A., \& Annamalai, V. (2011). Web Services and e-Shopping Decisions: A Study on Malaysian e-Consumer. International Journal of Computer Applications, 54-60.

31. Ratnasingham, P., \& Kumar, K. (2004). Trading Partner Trust In Electronic Commerce Participation. In Proceedings of Tenth Americas Conference on Information Systems (pp. 544-552).

32. Singh, N., Srivastava, S., \& Sinha, N. (2016). Consumer preference and satisfaction of M-Wallets: a study on North Indian consumers. International Journal of Bank Marketing.

33. Suresh, A. M., \& Shashikala, R. (2011). Identifying Factors of Consumer Perceived Risk towards Online Shopping in India. In 3rd International Conference on Information and Financial Engineering IPEDR (Vol. 12, pp. 366-341).

34. Tsai, Y. C., \& Yeh, J. C. (2010). Perceived risk of information security and privacy in online shopping: A study of environmentally sustainable products. African Journal of Business Management, 4(18), 4057-4066.

35. Tung, L., Tan, P., Chia, P., Koh, Y., \& Yeo, H.-L. (2001). An Empirical Investigation of Virtual Communities and Trust. In Twenty-Second International Conference on Information Systems (pp. 307-320).

36. Undang-Undang Republik Indonesia Nomor 8 Tahun 1999 Tentang Perlindungan Konsumen. (Customer Protection Act No. 8 of 1999)

37. Zhang, L., Tan, W., Xu, Y., \& Tan, G. (2012). Dimensions of Consumers ' Perceived Risk and Their Influences on Online Consumers ' Purchasing Behavior. Communications in Information Science and Management Engineering, 2(7), 8-14. 